\title{
COMPARISON BETWEEN TWO TYPES OF OCCLUSAL SPLINTS FOR TREATMENT OF ANTERIOR DISC DISPLACEMENT OF TMJ
}

\author{
Atef M. Hassaneen*
}

\begin{abstract}
This study was conducted to compare the final outcome of treatment of anterior disc displacement without reduction (ADDWoR) by using centric and anterior repositioning splints. Twenty patients, (16 females and 4 males) were included in this study with age ranged from 18-35 years, who were suffering from anterior disc displacement without reduction. Selected patients were divided into two equal groups; ten patients each according to the type of the occlusal splint. Group (I): included patients treated with a centric splints. Group(II): included patients treated with anterior repositioning splints. Clinical evaluation was performed before and after 15, 30, 90, and 180 days of splint therapy. Electromyography was done before and after three and six months post-treatment. Data were collected, tabulated, calculated and statistically analyzed. The results of this study showed that there was significant improvement in clinical and electromyographic results with no statistically significant difference between two types of used splints. It could be concluded that splint therapy as a non-invasive technique improved significantly symptoms of ADDWoR, regardless the type of splint used.
\end{abstract}

\section{INTRODUCTION}

Internal derangement of the temporomandibular joint (TMJ) may be defined as a disruption within the internal aspects of the TMJ in which there is a displacement of the disc from its normal functional relationship with the mandibular condyle and the articular portion of the temporal bone ${ }^{(1)}$. The disc is displaced in $35 \%$ of asymptomatic volunteers ${ }^{(2)}$. The American Academy of Orofacial Pain (AAOP) divides Tempromandibular dysfunction (TMD) into two syndromes: (1) muscle-related TMD (myogenous TMD), and (2) joint-related TMD (arthrogenous TMD). The two types can be present at the same time, making diagnosis and treatment more challenging ${ }^{(3)}$

TMJ derangement is mostly a disease of the stomatog-nathic system, and nonreducing disc displacement with reduced mouth opening in one type of the disorder, which is characterized by pain in the affected TMJ and a decrease range of mouth opening. The natural course of closed lock is self - limiting. However, if there is no significant improvement after 3 months of following a natural course of nonreducing disc displacement, therapy should be considered ${ }^{(4)}$.

* Lecturer of oral and maxillofacial surgery, Faculty of dental medicine, Al-Azhar University. 


\section{Clinical Stages of Internal Derangement Of Temporo-Mandibular Joint}

Internal derangement of the TMJ has been described as a progressive disorder that may be classified into four consecutive clinical stages ${ }^{(5)}$.

Stage One which is characterized clinically by clicking as a result of anterior disc displacement with reduction. The clinical hallmark of disc displacement with reduction is limited mouth opening, usually accompanied by deviation of the mandible to the involved side, until a pop or click (reduction) occurs. After the pop, the patient is able to open the mouth fully with a midline position of the mandible ${ }^{(5)}$.

Stage Two features are similar to that of stage one, plus additional episodes of limited mouth opening, which can last for various periods. The obstruction may disappear spontaneously or the patient may be able to manipulate the mandible beyond the interference ${ }^{(5)}$.

Stage Three : Closed lock (ADDWoR) occurs when clicking disappears but limited opening persists. Patient complains of TMJ pain and chronic limited opening, with the opening usually less than $30 \mathrm{~mm}$. Examination will reveal preauricular tenderness and deviation of the mandible to affected side with opening. In chronic closed lock episodes, if the condition progresses, the condyle may steadily push the disc forward to achieve almost normal ranges of mouth opening, in spite of the presence of a non-reducing $\operatorname{disc}^{4)}$.

Stage Four : as retrodiscal tissue continues to be stretched and loaded, it becomes subject to thinning and perforation. Anatomic studies have shown that this tissue may remodel before it succumbs, ill-adapted to the functional load, and perforates ${ }^{4}$ Wilkes's ${ }^{(6)}$ classification of TMJ disc displacement:

TMJ disk displacement has been categorized by Wilkes, using such criteria as severity of displacement and chronicity (Table -1$)$.
TABLE (1) Wilkes's classification of TMJ disc displacement

\begin{tabular}{|c|l|}
\hline Stage I & Early reducing disk displacement \\
\hline Stage II & Late reducing disk displacement \\
\hline Stage III & Nonreducing disk displacement: acute/subacute \\
\hline Stage IV & Nonreducing disk displacement :Chronic \\
\hline Stage V & $\begin{array}{l}\text { Nonreducing disk displacement: chronic with } \\
\text { osteoarthritis }\end{array}$ \\
\hline
\end{tabular}

It has been suggested that treatment modalities initially used for those disorders should be reversible and noninvasive ${ }^{(7)}$. Nonsurgical techniques that can decrease unintentional overloading of the masticatory system, eliminate pain, reduce dysfunction, and promote healing are essential in all phases of therapy ${ }^{(7)}$.

Surgical intervention for treatment of TMD should only be considered when all conservative treatment modalities have failed after at least 4-6 months. Surgical interventions include arthrocentesis, arthroscopy, and arthrotomy that include disc plication, meniscectomy, arthroplasty, and joint reconstruction is the most invasive surgical technique used to treat $\operatorname{TMD}^{(8,9)}$.

Nonsurgical Management may include: diet, pharmacotherapy (analgesics, anti-inflammatory medications, anxiolytics, antidepressants, muscle relaxants, local anesthetics), physical therapy and splint therapy ${ }^{(10-18)}$.

Conservative nonsurgical therapy should be attempted first and for proper period of time. The most common conservative therapy is the splint that associated with $90 \%$ success rate as reported by Clark ${ }^{(19)}$. On other hand the surgical intervention should be considered only for those cannot respond to nonsurgical therapy due to high potential complication and unpredictable result of the surgery ${ }^{(19)}$. Also the splint may be used to reposition the jaw in attempt to recapture the disc ${ }^{(18,20)}$. 
Splints refer to various appliances such as; bite plates bite planes, occlusal appliances, and others. Collectively they are usually acrylic devices that snap on to the dentition and disocclude the jaws ${ }^{(17,18)}$.

Centric splints are commonly used for treatment of masticatory dysfunction, TMJ pain, clicking and limitation of motion. It is constructed in centric relation position and may either cover maxillary or mandibular teeth ${ }^{(21)}$. Okeson et al ${ }^{(22)}$, evaluated 33 patients with TMJ pain for one month with centric splint, $85 \%$ showed decrease in pain score, maximum interincisal opening was improved. Eberhard D et al ${ }^{23)}$, investigated the efficacy of anterior repositioning splint using MRI. They mentioned that post insertion MRI showed no recapture of the disc in subjects with ADDWoR, while disc recapture was observed in 15 out of 18 subjects with ADDWR.

Stiesch-Scholz M et al ${ }^{(24)}$, compared pivot splint against centric splint in treatment of (ADDWoR), they concluded that both types of splints provided effective therapy in patients with (ADDWoR) without significant difference. Lous ${ }^{(25)}$ published the results in study of 60 clicking patients treated with pivots. The splints supplemented with vertical pull headgear attached to chin strap. The average treatment lasted 3-4weeks with follow up 3 months. $72 \%$ of the patients had elimination of symptoms. $17 \%$ had improvement but reoccurring symptom episodes. Because of limited occlusal contact with this splint there is a possibility of change in tooth position.

Harkins and Marteney ${ }^{(26)}$ tested soft splints in half of a sample of 84 patient who TMJ dysfunction. The other half served as control the splints were worn full time for 10-20 days. 10 of the patient stopped clicking, 64\% had less clicking, 7\% increased, and $19 \%$ had no change. Myalgia did not change in $26 \%$ of patients. Minor occlusion changes were noted in67\%. There was no change in control.
In a study that compared the outcome of treatment of TMD by Nociceptive Trigeminal Inhibitiontension suppression system (NTI-tss) splints and stabilization splints the investigator reported that there was no significant differences were noted between the two splints ${ }^{(27)}$.

Carlsson and Mgnusson ${ }^{(28)}$ mentioned that from a neurophysiologic point of view, thick appliance is more effective than thin one, but for comfort reason it should be as thin as possible.

Elelectromyography $(E M G)$ is a method to study the electrical activity of the muscle, to detect and characterize disease processes affecting the motor units $^{(29)}$, and to provide a guide to prognosis. EMG evaluations of the masticatory muscles constitute important resource to help the differential diagnosis and supply substantial surveying and management of suggested therapy ${ }^{(30)}$.

\section{PATIENTS AND METHODS}

The present study was conducted on twenty patients of both sexes suffering from anterior disc displacement without reduction of TMJ confirmed by clinical and radiographic examination with no congenital malformation and no previous surgical treatment in TMJ. They were 16 females and 4 males with mean age 26.5 (range, 18-35 years). They were selected from outpatient clinic of Oral and Maxillofacial Surgery Department, Faculty of Dental Medicine, Al-Azhar University.

Grouping of patients: patients were divided into two equal groups, 10 patients each. Group 1 included patients treated by maxillary centric splint (Fig.4a), while group 2 included patients treated by maxillary anterior repositioning splint (ARS) (Fig. 4b). 


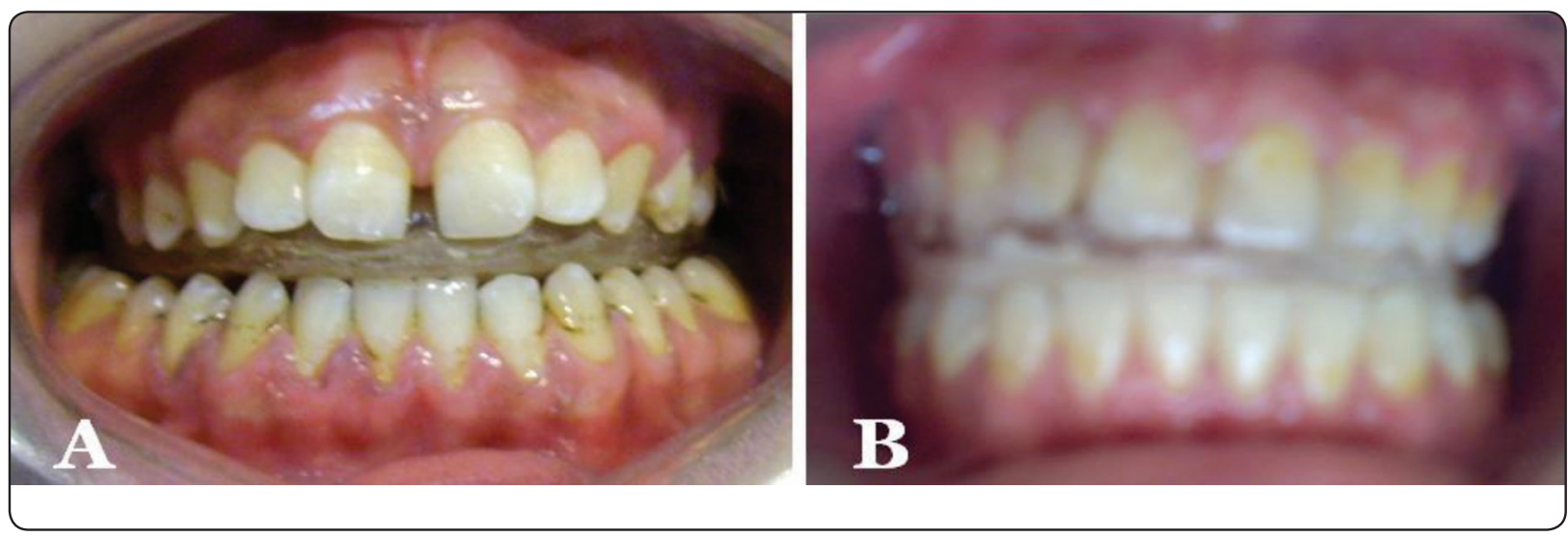

Fig (1) Intraoral photograph showing (A): Centric splint, and (B) Anterior reposition splint.

All patients were submitted to the following procedures:

\section{I-Clinical examination}

\section{1-Assessment of TMJ pain}

The maximal range of mouth opening between the incisal edges of the upper and lower incisors was measured and recorded as MMO. Lateral and protrusive ranges of motion were also measured. Pain was assessed using the visual analogue scale. The patients marked the level of their pain on a 0 -10 scale, with 0 representing no pain and 10 representing maximum pain ${ }^{(31)}$.

The TMJ was palpated bilaterally by index finger. The degree of the pain was recorded at each observation and given score value,

$$
0=\text { No pain, }
$$

$1=$ Mild pain,

$2=$ Moderate pain,

$3=$ Sever pain.

\section{2-Assessment of muscle tenderness}

Muscle tenderness was assessed by palpating each pair of the muscle bilaterally. Pain expressed in score from 0 to 3 . The palpated muscles include masseter, temporalis, lateral pterygoid, medial pterygoid, and sternomastoid muscles.

\section{3-Assessment of interincisal distance:}

Interincisal distance was recorded in millimeter by measuring the vertical distance between the incisal edges of the upper and lower central incisors (fig 5).
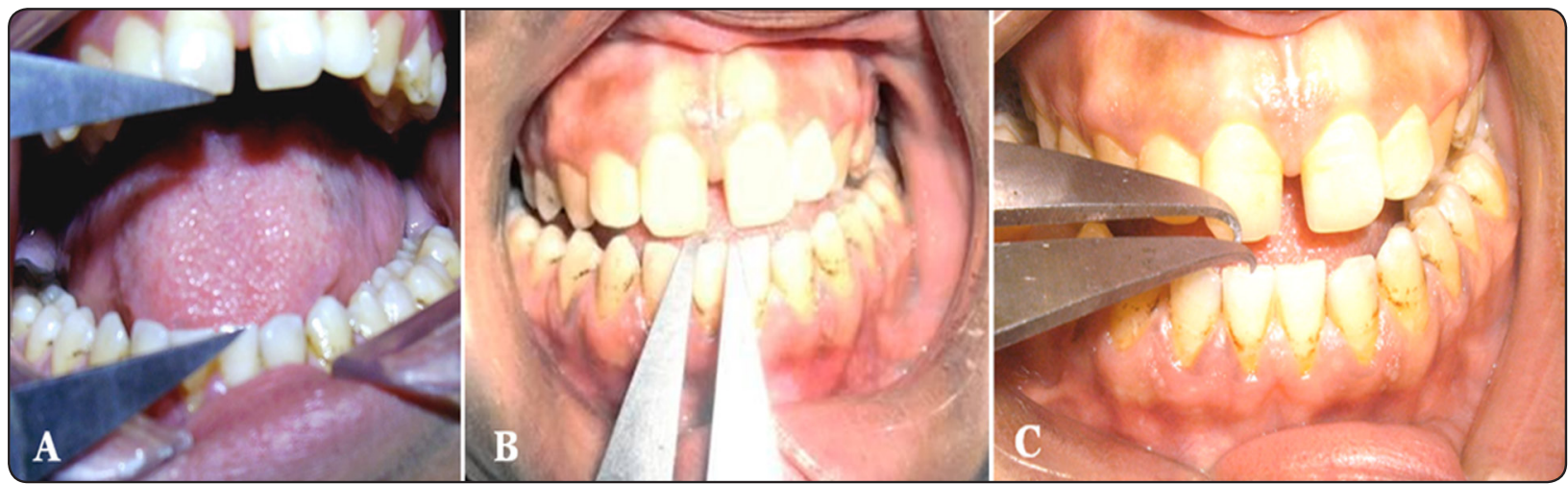

Fig (2) Dental measurements: (A) Interincisal distance, (B) Lateral movement and (C) Protrusive movement. 


\section{4- Assessment of lateral and protrusive jaw move- ments:}

Lateral movement was recorded in millimeter by measuring distance between midline of upper and lower central incisors (Fig. 2A). Right and left lateral movements summed and divided by 2 to give mean lateral movement (Fig. 2B). Protrusive jaw movement was recorded in millimeter by measuring the horizontal distance between the incisal edge of the labial surface of the upper and lower central incisors (Fig. 2C).

\section{II-Electromyography evaluation}

Registrations were obtained from right and left masseter and anterior temporalis muscles using electromyogram*. Recordings were performed before treatment, 3 and 6 months after treatment.

\section{Electrode position}

Bipolar surface electrodes with $14 \mathrm{~mm}$ interelectrode distance were used for registrations. Each subject held the ground electrode in the neck. In all subjects the electrodes were placed in a standardized position on the most active part of the selected muscles as the subject clenched. In the masseter muscle the electrodes were placed $1 \mathrm{~cm}$ behind the palpated anterior border in the area of greatest distension, parallel to the main direction of the fibers. In the anterior temporalis muscle the upper electrode was placed just in front of the anterior border of the hairline in the area of greatest lateral distension. The lower electrode was placed caudal to the first electrode, parallel to the main direction of the fibers.

\section{Splint fabrication}

Splints were fabricated after face bow records and mounting upper and lower casts on Hanu fully adjustable articulator in centric occluding position for centric splints and in edge to edge maxillarymandibular relation for anterior repositioning splints. Data were recorded, collected, tabulated, and statistically analyzed using independent " $\mathrm{t}$ " test to compare between both groups in each follow up period and paired " $\mathrm{t}$ " test to compare between different intervals in each group

\section{RESULTS}

\section{A) Clinical results:}

\section{1- Joint pain:}

Table (2-3), and Fig. (3) show the mean pain score value in TMJ before and after treatment for both groups through out the follow up period. There was no statistically significant difference between mean joint pain score of the two groups through all periods. There was a statistically significant decrease in mean joint pain scores through all periods in the both treatment groups.

TABLE (2) Shows changes in joint pain in both groups before and after treatment.

\begin{tabular}{|c|c|c|c|c|c|c|}
\hline \multirow{2}{*}{$\begin{array}{c}\text { Group } \\
\text { Period }\end{array}$} & \multicolumn{2}{|c|}{\begin{tabular}{c} 
Centric splint group \\
\cline { 2 - 6 }
\end{tabular}} & \multicolumn{2}{c|}{$\begin{array}{c}\text { Anterior repositioning } \\
\text { splint group }\end{array}$} & \multirow{2}{*}{$\boldsymbol{t}$-value } & $\boldsymbol{P}$-value \\
\cline { 2 - 7 } Preoperative & 2.1 & 0.3 & 2.2 & 0.4 & $\mathbf{- 0 . 6 0 3}$ & $\mathbf{0 . 5 5 5}$ \\
\hline $\mathbf{1 5}$ day & 1.6 & 0.5 & 1.8 & 0.4 & $\mathbf{- 0 . 9 7 0}$ & $\mathbf{0 . 3 4 6}$ \\
\hline $\mathbf{3 0}$ day & 1 & 0 & 1.3 & 0.5 & $\mathbf{- 2 . 0 0 0}$ & $\mathbf{0 . 0 6 3}$ \\
\hline $\mathbf{9 0}$ day & 1 & 0 & 1 & 0 & \multicolumn{2}{|c|}{ Not computed because SD of both groups = 0 } \\
\hline $\mathbf{1 8 0}$ day & 0.4 & 0.5 & 0.6 & 0.5 & $\mathbf{- 0 . 4 4 7}$ & $\mathbf{0 . 6 6 1}$ \\
\hline
\end{tabular}

\footnotetext{
* Nihon Kohden, made in Japan 2006, model JB-942BK
} 
TABLE (3) Show $\boldsymbol{P}$ value of joint pain in both groups at different treatment intervals.

\begin{tabular}{|c|c|c|c|c|c|}
\hline \multirow{3}{*}{$\begin{array}{c}\text { Centric splint } \\
\text { group }\end{array}$} & Mean difference & $\begin{array}{c}\text { Preoperative }- \\
15 \text { day }\end{array}$ & $\begin{array}{c}\text { Preoperative } \\
-30 \text { day }\end{array}$ & $\begin{array}{c}\text { Preoperative }-90 \\
\text { day }\end{array}$ & $\begin{array}{c}\text { Preoperative }-180 \\
\text { day }\end{array}$ \\
\cline { 2 - 6 } $\begin{array}{c}\text { Anterior } \\
\text { repositioning splint } \\
\text { group }\end{array}$ & P-value & $0.013^{*}$ & $<0.001^{*}$ & $<0.001^{*}$ & $<0.001^{*}$ \\
\cline { 2 - 6 } & Mean difference & $\begin{array}{c}\text { Preoperative }- \\
15 \text { day }\end{array}$ & $\begin{array}{c}\text { Preoperative } \\
-30 \text { day }\end{array}$ & $\begin{array}{c}\text { Preoperative }-90 \\
\text { day }\end{array}$ & $\begin{array}{c}\text { Preoperative }-180 \\
\text { day }\end{array}$ \\
\cline { 2 - 6 } & P-value & $0.035^{*}$ & $<0.001 *$ & $<0.001 *$ & $<0.001^{*}$ \\
\hline
\end{tabular}

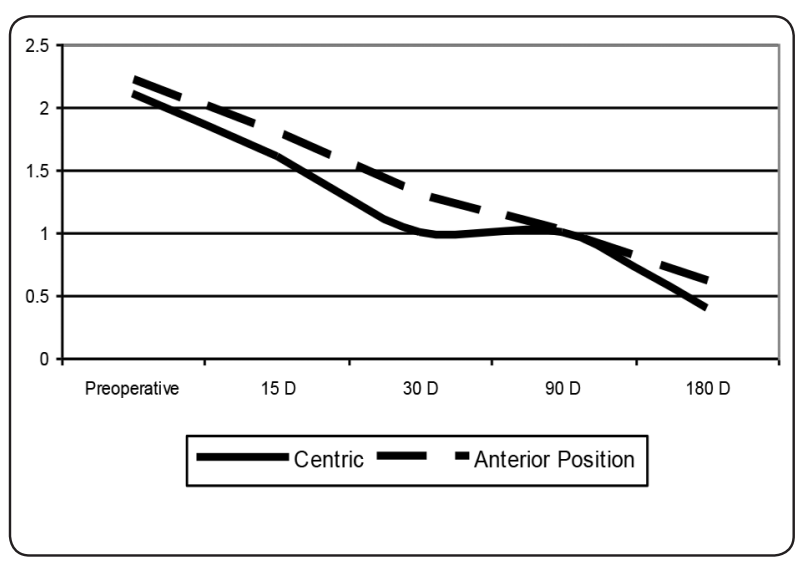

Fig. (3): Mean joint pain values before and after treatment for both groups through out the follow up periods.

\section{2- Muscle pain:}

Table (4) and Fig. (4) show that there was no statistically significant difference between mean muscle pain scores of the two groups through all periods.

Mean values of the masseter muscle pain score showed significant improvement through out the study period in both groups. Similarly, the mean temporalis muscle pain score showed significant improvement through out the study period in both groups.

Table (5) shows that in group I, there was a statistically significant decrease in mean pain score through all periods in masseter, temporalis and lateral pterygoid muscles.

TABLE (4) Show changes in muscle pain in both groups before and after treatment.

\begin{tabular}{|c|c|c|c|c|c|c|c|}
\hline \multirow{2}{*}{ Muscle } & \multirow{2}{*}{ Period } & \multicolumn{2}{|c|}{ Centric splint } & \multicolumn{2}{|c|}{ Anterior repositioning splint } & \multirow{2}{*}{ t-value } & \multirow{2}{*}{$P$-value } \\
\hline & & Mean & SD & Mean & SD & & \\
\hline \multirow{5}{*}{ Masseter } & Preoperative & 2.2 & 0.4 & 2 & 0.5 & 1.000 & 0.332 \\
\hline & 15 day & 1.6 & 0.5 & 1.7 & 0.5 & -0.459 & 0.653 \\
\hline & 30 day & 1.1 & 0.3 & 1.1 & 0.3 & 0.000 & 1.000 \\
\hline & 90 day & 1 & 0 & 0.9 & 0.3 & 1.000 & 0.332 \\
\hline & 180 day & 0.4 & 0.5 & 0.6 & 0.5 & -0.447 & 0.661 \\
\hline \multirow{5}{*}{ Temporalis } & Preoperative & 2.6 & 0.5 & 2.6 & 0.5 & 0.000 & 1.000 \\
\hline & 15 day & 1.7 & 0.5 & 1.9 & 0.3 & -1.109 & 0.284 \\
\hline & 30 day & 1 & 0 & 1.4 & 0.5 & -2.130 & 0.057 \\
\hline & 90 day & 1 & 0 & 1 & 0 & \multicolumn{2}{|c|}{---} \\
\hline & 180 day & 0.7 & 0.5 & 0.4 & 0.5 & 0.918 & 0.372 \\
\hline
\end{tabular}


TABLE (5) Show $\boldsymbol{P}$ value of muscle pain in both groups at different treatment intervals

\begin{tabular}{|c|c|c|c|c|c|c|}
\hline \multirow{4}{*}{ Centric splint } & \multirow[t]{2}{*}{ Masseter } & $\begin{array}{c}\text { Mean } \\
\text { difference }\end{array}$ & $\begin{array}{c}\text { Preoperative - } \\
15 \mathrm{da}\end{array}$ & $\begin{array}{c}\text { Preoperative - } \\
30 \text { day }\end{array}$ & $\begin{array}{c}\text { Preoperative - } \\
90 \text { day }\end{array}$ & $\begin{array}{c}\text { Preoperative - } \\
180 \text { day }\end{array}$ \\
\hline & & P-value & $0.004 *$ & $0.001 *$ & $<0.001 *$ & $<0.001 *$ \\
\hline & \multirow[t]{2}{*}{ Temporalis } & $\begin{array}{c}\text { Mean } \\
\text { difference }\end{array}$ & $\begin{array}{c}\text { Preoperative - } \\
15 \text { day }\end{array}$ & $\begin{array}{c}\text { Preoperative - } \\
30 \text { day }\end{array}$ & $\begin{array}{c}\text { Preoperative - } \\
90 \text { day }\end{array}$ & $\begin{array}{c}\text { Preoperative - } \\
180 \text { day }\end{array}$ \\
\hline & & P-value & $0.002 *$ & $<0.001 *$ & $<0.001 *$ & $<0.001 *$ \\
\hline \multirow{4}{*}{$\begin{array}{c}\text { Anterior } \\
\text { repositioning } \\
\text { splint }\end{array}$} & \multirow[t]{2}{*}{ Masseter } & $\begin{array}{c}\text { Mean } \\
\text { difference }\end{array}$ & $\begin{array}{c}\text { Preoperative - } \\
15 \text { day }\end{array}$ & $\begin{array}{c}\text { Preoperative - } \\
30 \text { day }\end{array}$ & $\begin{array}{c}\text { Preoperative - } \\
90 \text { day }\end{array}$ & $\begin{array}{c}\text { Preoperative - } \\
180 \text { day }\end{array}$ \\
\hline & & P-value & 0.081 & $<0.001 *$ & $<0.001 *$ & $<0.001^{*}$ \\
\hline & \multirow[t]{2}{*}{ Temporalis } & $\begin{array}{c}\text { Mean } \\
\text { difference }\end{array}$ & $\begin{array}{c}\text { Preoperative - } \\
15 \text { day }\end{array}$ & $\begin{array}{c}\text { Preoperative - } \\
30 \text { day }\end{array}$ & $\begin{array}{c}\text { Preoperative - } \\
90 \text { day }\end{array}$ & $\begin{array}{c}\text { Preoperative - } \\
180 \text { day }\end{array}$ \\
\hline & & P-value & $0.022 *$ & $0.001 *$ & $<0.001 *$ & $<0.001 *$ \\
\hline
\end{tabular}

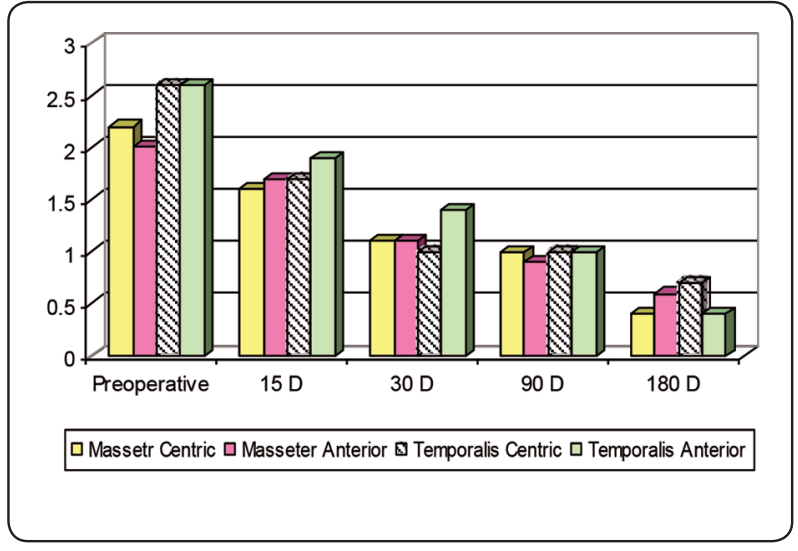

Fig (4) A bar chart showing mean muscle pain values in both groups through out the follow up periods.

\section{3- Inter-incisal distance:}

Table (6), and Fig. (5) show the mean active and passive interincisal distance at maximum mouth opening before and after treatment for both groups. In group I, the mean active mouth opening was $24.4 \mathrm{~mm}$ before treatment, and 26.6,34.7,38.7, and $43.2 \mathrm{~mm}$ at $15,30,90$, and 180 days post treatment respectively, while the mean passive mouth opening was $29.4 \mathrm{~mm}$ before treatment, and $30.8,37.4$, 40.1 , and $46.3 \mathrm{~mm}$ at $15,30,90$, and 180 days post treatment respectively.

In group II, the mean active mouth opening was $25.3 \mathrm{~mm}$ before treatment, and 26.6, 34.7, 38.7, and $43.2 \mathrm{~mm}$ at $15,30,90$, and 180 days post treatment respectively, while the mean passive mouth opening was $30 \mathrm{~mm}$ before treatment, and 31.5, 37.3, 40.8, and $45.1 \mathrm{~mm}$ at $15,30,90$, and 180 days post treatment respectively. There was no statistically significant difference between mean interincisal distances of the two groups through all periods.

By mean of paired t-test, it was found that in group I, there was a statistically significant increase in mean interincisal distance through all periods. In group II, there was a statistically significant increase in mean interincisal distance through all periods except at 15 days (passive movement), where there was no statistically significant difference Table (7) and Fig (5). 
TABLE (6) Show changes in interincisal distance in both groups before and after treatment.

\begin{tabular}{|c|c|c|c|c|c|c|}
\hline \multirow{2}{*}{ Group } & \multicolumn{2}{|c|}{ Centric splint group } & \multicolumn{2}{|c|}{ Anterior repositioning splint group } & \multirow{2}{*}{ t-value } & P-value \\
\cline { 2 - 7 } & Mean & SD & Mean & SD & \\
\hline Preoperative & 24.4 & 3 & 25.3 & 2.2 & -0.712 & 0.487 \\
\hline 15 day & 26.6 & 3.1 & 26.8 & 2.3 & -0.173 & 0.865 \\
\hline 30 day & 34.7 & 2.7 & 34.1 & 2.4 & 1.157 & 0.508 \\
\hline 90 day & 38.7 & 2.2 & 37.4 & 2.5 & 0.963 & 0.350 \\
\hline 180 & 43.2 & 1.8 & 42.2 & 2.7 & & \\
\hline
\end{tabular}

TABLE (7) Show $\boldsymbol{P}$ value of interincisal distance in both groups at different treatment intervals.

\begin{tabular}{|c|c|c|c|c|c|}
\hline \multirow{2}{*}{$\begin{array}{c}\text { Centric splint } \\
\text { group }\end{array}$} & Mean difference & $\begin{array}{c}\text { Preoperative }-15 \\
\text { day }\end{array}$ & $\begin{array}{c}\text { Preoperative }-30 \\
\text { day }\end{array}$ & $\begin{array}{c}\text { Preoperative }-90 \\
\text { day }\end{array}$ & $\begin{array}{c}\text { Preoperative }-180 \\
\text { day }\end{array}$ \\
\cline { 2 - 6 } & P-value & $<0.001 *$ & $<0.001 *$ & $<0.001 *$ & $<0.001^{*}$ \\
\hline $\begin{array}{c}\text { Anterior } \\
\text { repositioning } \\
\text { splint group }\end{array}$ & Mean difference & $\begin{array}{c}\text { Preoperative }-15 \\
\text { day }\end{array}$ & $\begin{array}{c}\text { Preoperative }-30 \\
\text { day }\end{array}$ & $\begin{array}{c}\text { Preoperative }-90 \\
\text { day }\end{array}$ & $\begin{array}{c}\text { Preoperative }-180 \\
\text { day }\end{array}$ \\
\cline { 2 - 6 } & P-value & $0.001 *$ & $<0.001 *$ & $<0.001 *$ & $<0.001^{*}$ \\
\hline
\end{tabular}

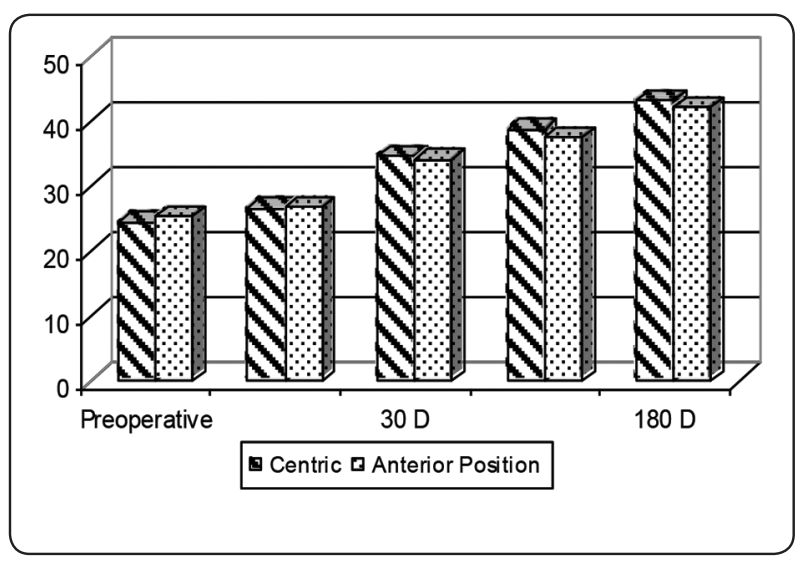

Fig (5) A bar chart showing the mean interincisal distance in both groups through out follow up periods.

\section{4- Lateral movement}

Table (8), and Fig. (6) show the mean lateral movement before and after treatment for both groups. In group I, the mean lateral movement was $4.8 \mathrm{~mm}$ before treatment, and 5.9, 7.8, 8.6, and $9.9 \mathrm{~mm}$ at $15,30,90$, and 180 days post treatment respectively.

In group II, the mean lateral movement was $4.8 \mathrm{~mm}$ before treatment, and 5.6, 7.6, 8.4, and $9.4 \mathrm{~mm}$ at $15,30,90$, and 180 days post treatment respectively. There was no statistically significant difference between mean lateral movements of the two groups through all periods. By mean of paired t-test it was found that, there was a statistically significant difference in mean lateral movement through all periods in the two groups Table (9). 
TABLE (8) Show changes in the lateral movement in both groups before and after treatment

\begin{tabular}{|c|c|c|c|c|c|c|}
\hline \multirow[b]{2}{*}{ Period } & \multicolumn{2}{|c|}{ Centric splint group } & \multicolumn{2}{|c|}{ Anterior repositioning splint group } & \multirow{2}{*}{ t-value } & \multirow{2}{*}{ P-value } \\
\hline & Mean & SD & Mean & SD & & \\
\hline Preoperative & 4.8 & 1.6 & 4.8 & 0.9 & 0.000 & 1.000 \\
\hline 15 day & 5.9 & 1.7 & 5.6 & 1.1 & 0.492 & 0.630 \\
\hline 30 day & 7.8 & 1.2 & 7.6 & 1.1 & 0.413 & 0.685 \\
\hline 90 day & 8.6 & 0.9 & 8.4 & 1 & 0.517 & 0.612 \\
\hline 180 day & 9.9 & 0.9 & 9.4 & 0.7 & 1.447 & 0.167 \\
\hline
\end{tabular}

Table (9) Show $\boldsymbol{P}$ value of the lateral movement in both groups at different treatment intervals.

\begin{tabular}{|c|c|c|c|c|c|}
\hline \multirow{2}{*}{$\begin{array}{c}\text { Centric splint } \\
\text { group }\end{array}$} & Mean difference & $\begin{array}{c}\text { Preoperative }- \\
15 \text { day }\end{array}$ & $\begin{array}{c}\text { Preoperative }- \\
30 \text { day }\end{array}$ & $\begin{array}{c}\text { Preoperative }- \\
90 \text { day }\end{array}$ & $\begin{array}{c}\text { Preoperative }- \\
180 \text { day }\end{array}$ \\
\cline { 2 - 6 } & P-value & $<0.001^{*}$ & $<0.001^{*}$ & $<0.001^{*}$ & $<0.001^{*}$ \\
\hline \multirow{2}{*}{$\begin{array}{c}\text { Anterior } \\
\text { repositioning } \\
\text { splint group }\end{array}$} & Mean differences & $\begin{array}{c}\text { Preoperative }- \\
15 \text { day }\end{array}$ & $\begin{array}{c}\text { Preoperative }- \\
30 \text { day }\end{array}$ & $\begin{array}{c}\text { Preoperative }- \\
90 \text { day }\end{array}$ & $\begin{array}{c}\text { Preoperative }- \\
180 \text { day }\end{array}$ \\
\cline { 2 - 6 } & P-value & $0.002 *$ & $<0.001^{*}$ & $<0.001 *$ & $<0.001 *$ \\
\hline
\end{tabular}

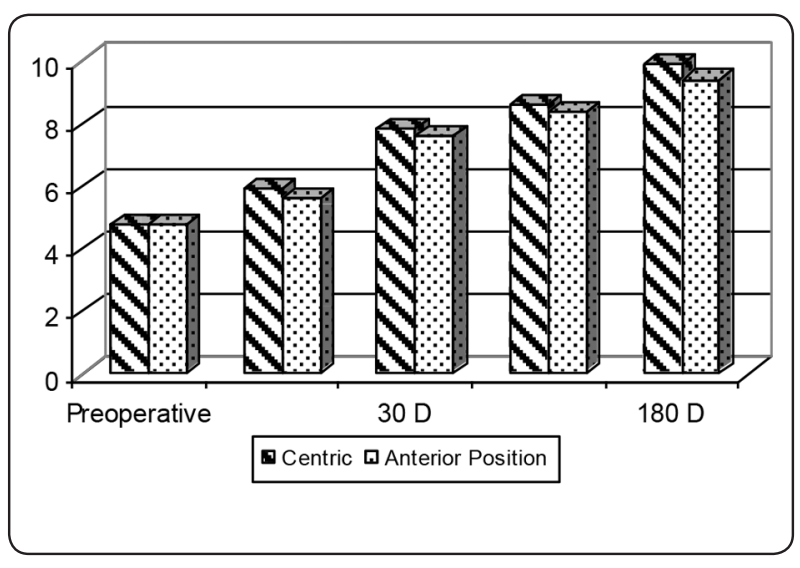

Fig (5) A bar chart showing the mean lateral distance in both groups through out follow up periods.

\section{5- Protrusive movement}

Table (10) and Fig. (6) show the mean protrusive movement before and after treatment for both groups. In group I, the mean protrusive movement was $5.8 \mathrm{~mm}$ before treatment, and 6.5 , $8.1,9.1$, and $10.5 \mathrm{~mm}$ at $15,30,90$, and 180 days post treatment respectively. In group II, the mean protrusive movement was $6.2 \mathrm{~mm}$ before treatment, and $7.1,9.1,9.5$, and $11.2 \mathrm{~mm}$ at $15,30,90$, and 180 days post treatment respectively. There was no statistically significant difference between mean protrusive movements of the two groups through all periods. By mean of paired t-test it was found that, there was a statistically significant increase in mean protrusive movement through all periods in the two groups Table (11). 
TABLE (10) Show changes in the protrusive movement in both groups before and after treatment.

\begin{tabular}{|c|c|c|c|c|c|c|}
\hline \multirow{2}{*}{ Period } & \multicolumn{2}{|c|}{ Centric splint group } & \multicolumn{2}{c|}{$\begin{array}{c}\text { Anterior repositioning splint } \\
\text { group }\end{array}$} & \multirow{2}{*}{ t-value } & P-value \\
\cline { 2 - 5 } & Mean & SD & Mean & SD & & \\
\hline Preoperative & 5.8 & 0.8 & 6.2 & 1.6 & -0.760 & 0.458 \\
\hline 15 day & 6.5 & 0.8 & 7.1 & 1.4 & -1.163 & 0.262 \\
\hline 30 day & 8.1 & 0.6 & 9.1 & 1.7 & -1.705 & 0.108 \\
\hline 90 day & 9.1 & 0.5 & 9.5 & 1.6 & -0.809 & 0.430 \\
\hline 180 day & 10.5 & 0.7 & 11.2 & 1.5 & -1.206 & 0.245 \\
\hline
\end{tabular}

TABLE (11): Show $\boldsymbol{P}$ value of the protrusive movement in both groups at different treatment intervals

\begin{tabular}{|c|c|c|c|c|c|}
\hline \multirow{2}{*}{$\begin{array}{c}\text { Centric splint } \\
\text { group }\end{array}$} & $\begin{array}{c}\text { Mean } \\
\text { difference }\end{array}$ & $\begin{array}{c}\text { Preoperative }- \\
15 \text { day }\end{array}$ & $\begin{array}{c}\text { Preoperative }- \\
30 \text { day }\end{array}$ & $\begin{array}{c}\text { Preoperative }- \\
90 \text { day }\end{array}$ & $\begin{array}{c}\text { Preoperative }- \\
180 \text { day }\end{array}$ \\
\cline { 2 - 6 } & P-value & $<0.001^{*}$ & $<0.001^{*}$ & $<0.001^{*}$ & $<0.001^{*}$ \\
\hline $\begin{array}{c}\text { Anterior } \\
\text { repositioning } \\
\text { splint group }\end{array}$ & $\begin{array}{c}\text { Mean } \\
\text { difference }\end{array}$ & $\begin{array}{c}\text { Preoperative }- \\
15 \text { day }\end{array}$ & $\begin{array}{c}\text { Preoperative }- \\
30 \text { day }\end{array}$ & $\begin{array}{c}\text { Preoperative }- \\
90 \text { day }\end{array}$ & $\begin{array}{c}\text { Preoperative }- \\
180 \text { day }\end{array}$ \\
\cline { 2 - 6 } & P-value & $0.009^{*}$ & $<0.001^{*}$ & $<0.001^{*}$ & $<0.001^{*}$ \\
\hline
\end{tabular}

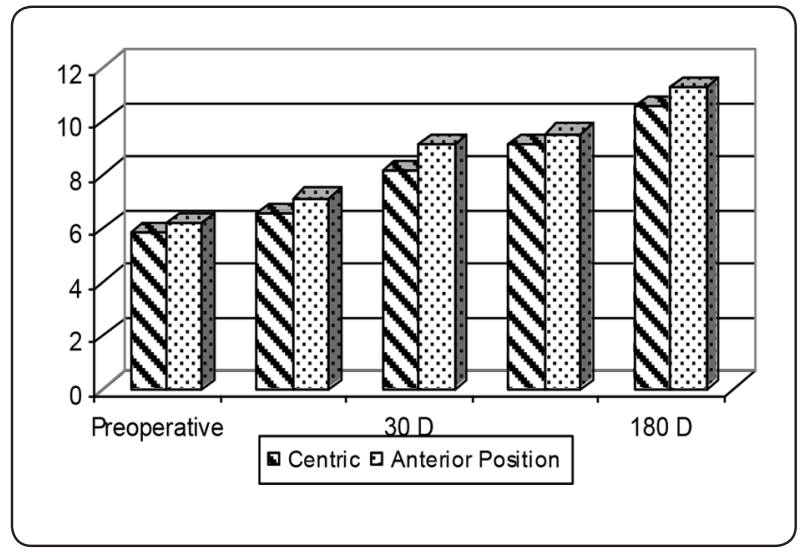

Fig (6) A bar chart showing the mean protrusive distance in both groups through out follow up periods.

\section{7- Electromyography:}

Table $(12)$, and Fig. $(7,8)$ show the mean EMG of masseter and temporal muscles in both groups before and after treatment. In group I, the mean amplitude of masseter muscle was 123.8, 298.2, and $484.2 \mu \mathrm{v}$ before treatment, and at 3 , and 6 months after treatment respectively. The mean amplitude of temporalis muscle was $162.4,320.4$, and 494.9 $\mu \mathrm{v}$ before treatment, and at 3 , and 6 months after treatment respectively. In group II, the mean amplitude of masseter muscle was 156.9, 298.3, and $482.2 \mu \mathrm{v}$ before treatment, and at 3 , and 6 months after treatment respectively. The mean duration of masseter muscle was $13.2,9.1$, and $4.1 \mathrm{msec}$ before treatment, and at 3, and 6 months after treatment respectively. The mean amplitude of temporalis muscle was $119.5,289.4$ and $471.7 \mu \mathrm{v}$ before treatment, and at 3, and 6 months after treatment respectively. There was no statistically significant difference of the mean amplitude in both groups for both muscles through all follow up periods. By mean of paired t-test it was found that, there was a statistically significant increase in mean amplitude through all periods with the two muscles in the two groups, while there was a statistically significant decrease in mean duration through all periods with the two muscles in the two groups Table (13). 
TABLE (12) Show changes in EMG in both groups before and after treatment.

\begin{tabular}{|c|c|c|c|c|c|c|c|}
\hline \multirow[t]{2}{*}{ Muscle } & \multirow[b]{2}{*}{ Period } & \multicolumn{2}{|c|}{ Centric splint group } & \multicolumn{2}{|c|}{$\begin{array}{l}\text { Anterior repositioning splint } \\
\text { group }\end{array}$} & \multirow[t]{2}{*}{ t-value } & \multirow[t]{2}{*}{ P-value } \\
\hline & & Mean & SD & Mean & SD & & \\
\hline \multirow{3}{*}{$\begin{array}{l}\text { Anterior } \\
\text { Temporal }\end{array}$} & Preoperative & 162.4 & 28.4 & 156.9 & 11.1 & 1.217 & 0.155 \\
\hline & 3 month & 320.4 & 52.4 & 298.3 & 21.4 & 1.967 & 0.069 \\
\hline & 6 month & 494.9 & 37 & 482.2 & 26 & 1.756 & 0.087 \\
\hline \multirow{3}{*}{ Masseter } & Preoperative & 123.8 & 35.4 & 119.5 & 15.1 & 0.763 & 0.806 \\
\hline & 3 month & 298.2 & 41.1 & 289.4 & 20.7 & 1.045 & 0.208 \\
\hline & 6 month & 484.2 & 12 & 471.7 & 17.2 & 0.907 & 0.910 \\
\hline
\end{tabular}

TABLE (13) Show $\boldsymbol{P}$ value of EMG in both groups at different treatment intervals.

\begin{tabular}{|c|c|c|c|c|}
\hline \multirow{4}{*}{$\begin{array}{l}\text { Centric splint } \\
\text { group }\end{array}$} & \multirow{2}{*}{$\begin{array}{l}\text { Anterior } \\
\text { Temporal }\end{array}$} & Mean difference & Preoperative -3 month & Preoperative -6 month \\
\hline & & P-value & $<0.001 *$ & $<0.001 *$ \\
\hline & \multirow{2}{*}{ Masseter } & Mean difference & Preoperative -3 month & Preoperative -6 month \\
\hline & & $\mathrm{P}$-value & $<0.001 *$ & $<0.001 *$ \\
\hline \multirow{4}{*}{$\begin{array}{c}\text { Anterior } \\
\text { repositioning splint } \\
\text { group }\end{array}$} & \multirow{2}{*}{$\begin{array}{l}\text { Anterior } \\
\text { Temporal }\end{array}$} & Mean difference & Preoperative -3 month & Preoperative -6 month \\
\hline & & P-value & $<0.001 *$ & $<0.001 *$ \\
\hline & \multirow{2}{*}{ Masseter } & Mean difference & Preoperative -3 month & Preoperative -6 month \\
\hline & & $\mathrm{P}$-value & $<0.001 *$ & $<0.001 *$ \\
\hline
\end{tabular}

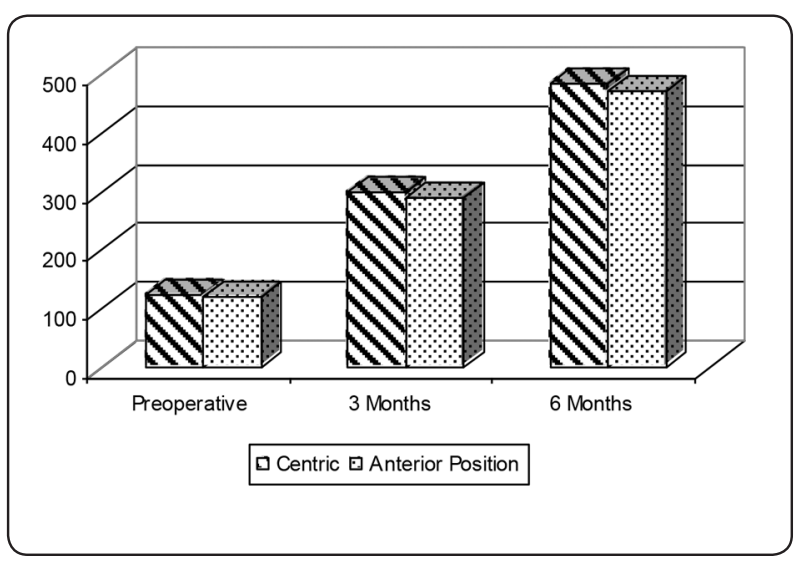

Fig (7) A bar chart showing the mean amplitude of the masseter muscle in both groups through out the follow up periods.

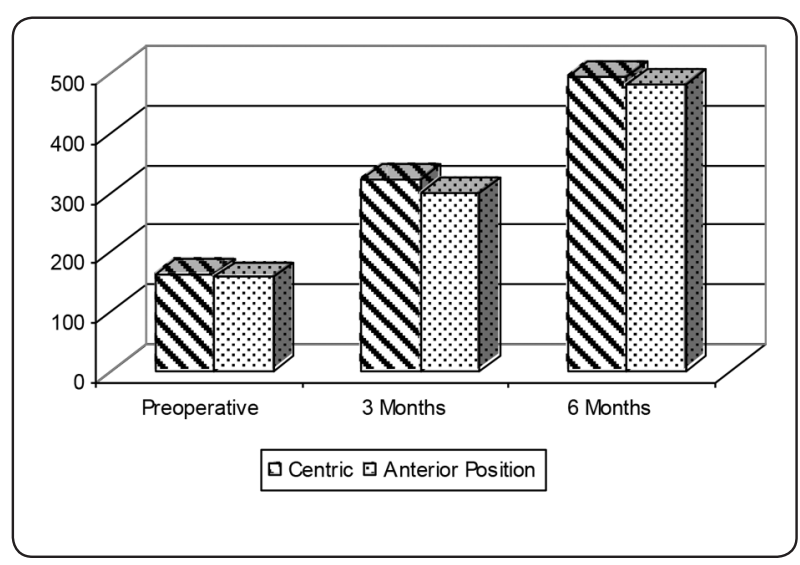

Fig (8) A bar chart showing the mean amplitude of the temporalis muscle in both groups through out the follow up periods. 


\section{DISCUSSION}

Anterior disc displacement without reduction is considered one of the most advanced stages of temporomandibular disorders. This condition results in several signs and symptoms including sever pain and limitation of function.

The present study was conducted on 20 patients of both sexes who were candidates for conservative treatment of anterior disc displacement without reduction of TMJ. They were 16 females and 4 males with mean age 26.5 (range, 18-35 years). They were selected from those attending the outpatient clinic of Oral and Maxillofacial Department, Faculty of Dental Medicine, Al-Azhar University. Subjects were excluded from this study if they had congenital malformation in TMJ region, previous surgical treatment in TMJ or had any current systemic disease that may affect muscle function or bone.

In this study the diagnosis of ADDWoR was confirmed by MRI scans as it is considered the golden standard in diagnosis of TMD ${ }^{31}$. Conservative nonsurgical therapy should be attempted first and for proper period of time. and surgical intervention should be considered only for those who do not respond to nonsurgical therapy due to high potential complication and unpredictable results of the surgery ${ }^{7}$. The most common conservative therapy is the splint that associated with $90 \%$ success rate as reported by Clark, (1983) ${ }^{32}$. This antagonizes the results reported by Sato et al ${ }^{33)}$ who compared patients using a centric splint with a control group (no treatment) and found no statistically significant differences between both groups.

In this study the maxillary splints were used as they get stable position with good retention and adequate cuspid guidance, while mandibular splints, encroache on the space normally occupied by the tongue. ${ }^{(31)}$. In group I and II there was a significant decrease in the joint pain and there was no statistical significant difference between both groups. This is in agreement with the study of Schmitter et al ${ }^{(20)}$.
The current study showed that centric and anterior repositioning splints are effective in reducing the masticatory muscle pain that associated with TMD. However, there was no statistical significant difference between groups. Centric splint provide slightly better improvement. This in agreement with Schmitter et al ${ }^{(20}$, Williamson $\mathrm{EH}^{35)}$, Le Bell Y and Forssell $\mathrm{H}^{(36)}$, and Lundh $\mathrm{H}$ et al ${ }^{(37)}$. The efficacy of the splint is thought to be due to either reduction of the applied bite forces which is accompanied by reduction on the joint load or due to occlusal decoupling which may cause reorientation of neuromuscular reflex mechanisms.

In the present study, the mean mouth opening after 6 months was $43.2 \mathrm{~mm}$ and $42.2 \mathrm{~mm}$ for centric and anterior repositioning splint groups respectively with no significant difference between both types of splints which was in agreement with Schmitter et al ${ }^{(20)}$. The present study showed that significant improvement in lateral and protrusive jaw movements with no statistical significant difference between both groups. This is comparable with the results of results of other studies $(20,24,35,35)$

In the present study the effect of two types of splints on muscle activities was analyzed. There was significant improvement in the muscle acitivity in both temporalis and masseter muscles by time with no significant difference between both groups through out follow up periods. This is in agreement with other researches ${ }^{(35-37)}$.

\section{REFERENCES}

1- Dolwick MF, Katzberg RW and Helms CA: Internal derangement of temporomandibular joint: fact or fiction? J Prothet Dent 49:415-8;1983.

2- Ribeiro RF, Tallents RH, Katzberg RW, Murphy WC, Moss ME, Magalhaes AC and other: The prevalence of disc displacement in symptomatic and asymptomatic volunteers aged 6-25 years. J Orofac Pain11:37-47; 1997.

3- Okeson JP: American Academy of Orofacial Pain. Orofacial Pain: Guidelines for Assessment, Diagnosis, and Management. 3rd ed. Chicago: Quintessence Publishing; 1996. 
4- Miernik M, Wieckiewicz W. The basic conservative treatment of temporomandibulr joint anterior disc displacement without reduction review. Adv Clin Exp Med 24:731-735;2015.

5- Kaplan A: Natural history of internal derangement of the temporomandibular joint. In: Thomas M, BronsteinS, editor. Arthroscopy of temporomandibular joint. Philadelphia: WB Sunders.p.70-4; 1991.

6- Wilkes CH:Internal derangement of the temporomandibular joint pathological variations. Arch Otolaryngol Head Neck Surg 115:469-771989.

7- Beek M, Aarnts MP, Koolstra JH, Feilzer AJ and van Eijden TMGJ: Dynamic properties of the human temporomandibular joint disc. J Dent Res 80:876-80; 2001.

8- Leslie B. Heffez: Principles of oral and maxillofacial surgery. Ch. 68, Vol. 3. Surgery for internal derangements of temporomandibular joint disorders. Lippincott-Raven Publishers, Philadelphia; 1997.

9- Thompson IO, Berezowski BM, van Wyk CW and Phillips VM: Synovial chondromatosis: Report of a rare surgical problem of the temporomandibular joint. J Dent Assoc S Afr 50:333-7; 1995.

10- Raphael KG, Marbach JJ and Touger-Decker R: Dietary fiber intake in patients with myofacial face pain, J Orofac Pain 16:39-47;2002.

11- Fordyce WE: On opioids and treatment targets. Am Pain Soc Bull 1:1-13; 1991.

12- Syrop S: Pharmacologic management of myofascial pain and dysfunction. Oral Maxillofac Surg Clin North Am 7:87-97; 1995.

13- Kerrick JM, Fine PG, Lipman AG and Love G: Low dose amitriptyline as an adjunct to opioids for postoperative orthopedic pain: a placebo controlled trial. Pain 52:32530; 1993.

14- Freund B, Schwartz M and Symington JM: Botulism toxin: new treatment for temporomandibular disorders. $\mathrm{Br}$ J Oral Maxillofac Surg 38:466-71; 2000.

15- Guarda NL, Tito $\mathrm{R}$ and Beltrame A: Treatment of temporomandibular joint closed lock using intra-articular injection of mepivacaine with immediate resolution durable in time (six month follow-up) [Italian]. Minerva Stomatol 51(1-2):21-8; 2002.
16- Clark GT, Adachi NY and Dorman MR: Physical medicine procedures affect temporomandibular disorders: A review. J Am Dent Assoc 121: 151;1990.

17 Lundh, H: Correction of temporomandibular joint disk displacement by occlusal therapy. Swed Dent J, 51-7; 1987.

18- Steven B Syrop: Principles of oral and maxillofacial surgery. Ch. 67, Vol. 3. Nonsurgical management of temporomandibular disorders Lippincott-Raven Publishers, Philadelphia; 1997.

19- Clarck GT: Occlusal appliance: In the president's conference on the examination, diagnosis, and management of temporomandibular disorders, Chicago, Am Dent Assoc PP: $137 ; 1983$.

20- Schmitter M, Zabran M, Phu Duc JM, Henschel V and Rammelsberg P: Conservative therapy in patient with anterior disc displacement without reduction using 2 common splints: randomized clinical trail. J Oral Maxillofag Surg 63:1295-303; 2005.

21- Boero RP: The physiology of splint therapy: a literature review. Angle Orthod 59 (3):165-80; 1989.

22- Okeson, Kemper and Moody: A study of the use of occlusion splints in the treatment of the acute and chronic patients with craniomandibular disorders. J Prothet Dent 48:708; 1982.

23- Eberhard D, BantleonHP and Steger W: The efficacy of anterior repositioning splint therapy studied by magnetic resonance imaging. Eur J orthod 24:343-52; 2002.

24- Stiesch-Scholz M, Kempert J, Wolter S, Tschrintschekand and Rossbach: Comparative prospective study on splint therapy on anterior disc displacement without reduction. J Oral Rehabil 32:474-9; 2005.

25- Lous: Treatment of TMJ syndrome by pivots. J Prothet Dent 40; 179; 1978.

26- Harkins, Marteney, Cueva and Cueva: Application of soft occlusal splints in patient suffering from clicking temporomandibular joint. Cranio 6:72;1988.

27- Jokstad A, Mo A and Krogstad BS: Clinical comparison between two different splint designs for temporomandibular disorders therapy. Acta Odontol Scand 63:19; 2005.

28- Carlsson G and Magnusson T: Management of temporomandibular disorders in general dental Practice. Chapter II, QuintessencePublishing Co. Inc; PP: 101-103,1999. 
29- Blijham PJ, Hengstman GJ, Ter laak HJ, Van Englen BC and Zwarts MJ: Muscle fiber conduction velocity and electromyography as diagnostic tools in patient with suspected inflammatory myopathy: a prospective study. Muscle Nerve 29:46;2004.

30- Kawazoe Y, Kotani H, Hamada T and Yamada S: Effect of occlusal splints on electromyographic activities of masseter muscles during maximum clenching in patient with myofacial pain-dysfunction syndrome. J Prothet Dent 43:578; 1980.

31- Tvrdy P, Heinz P, Zapletalova J, Pink R, Michl P. Effect of combinaton therapy of arthrocentesis and occlusal splint on non reducing temporomandibular joint disk displacement . Biomed Pap Med Fac univ palacky Olomouc Czech Repub 159:677-680;2015.

32- Schellhas KP: imaging of temporomandibular joint. Oral Maxillofac Surg Clin North Am 1:13-26; 1989.

33- Clarck GT: Occlusal appliance: In the president's conference on the examination, diagnosis, and management of temporomandibular disorders, Chicago, Am Dent Assoc PP: $137 ; 1983$.

34- Sato S, Kawamura II and Motigo K: Management of nonreducing temporomandibular joint disk displacement. Evaluation of three treatments. Oral Surg Oral Med Oral Pathol Oral Radiol Endod 80:384; 1995.

35- Cassisi JE, McGlynn FD and Mahan PE: Occlusal splint effects on nocturnal bruxing: An emerging paridium and some early result. Craniomand Pract 5(1):65-8; 1987.

36- Williamson EH: Temporomandibular dysfunction and repositioning splint therapy. Prog Orthod 6(2):206-13; 2005.

37- Le Bell Y and Forssell H: A two-year follow-up of temporomandibular joint disk displacement without reduction in 22 subjects. Proc Finn Dent Soc. 89(1-2):45$50 ; 1993$.

38- Lundh H, Westesson PL, Eriksson L and Brooks SL: Temporomandibular joint disk displacement without reduction. Treatment with flat occlusal splint versus no treatment. Oral Surg Oral Med Oral Pathol 73(6):655-8; 1992. 